\title{
Development of Regionalism : New Criteria and Typology
}

\author{
Yoo-Duk Kang \\ Korea Institute for International Economic Policy, Sejong-si, Republic of Korea
}

\begin{abstract}
This study examines the development of regionalism and the different typologies of Regional Trade Agreements. Beginning with Balassa's typology, it conducts an overview of commonly used typologies of regionalism and emphasizes that the previous typologies do not reflect the different features of Regional Trade Agreements, for example, the external factors that make it possible to differentiate between seemingly similar types of Regional Trade Agreements. After noticing these limitations, we propose a new typology of Regional Trade Agreements and its criteria by combining the existing methods and the new one. Recent Regional Trade Agreements can be regarded as responses to a new trade environment: Multilateral negotiations agenda and globalization. This is probably why recent Regional Trade Agreements are often termed as World Trade Organizationplus. In the context of emerging mega-Regional Trade Agreements, such as the TransPacific Partnership and the Regional Comprehensive Economic Partnership, this study calls for more efforts toward harmonizing the different Regional Trade Agreements or creating a template of standard Regional Trade Agreements in order to prevent a spaghetti bowl effect. Meanwhile, Mega-Regional Trade Agreements also seem to be influenced by the consequences of the 2008 2009 global financial crisis.
\end{abstract}

\footnotetext{
* Corresponding Author: Yoo-Duk Kang; Department of Europe, Americas and Eurasia, Korea Institute for International Economic Policy, Sejong National Research Complex, 370 Sicheongdaero, Sejong-si, 339-007, Republic of Korea; Tel: +82 444141123, Fax: +82 444141044, E-mail: ydkang@kiep.go.kr.
} 
JEL Classifications: F13, F15, F59

Keywords: Balassa's Typology, Regionalism, Regionalization, Free Trade Agreement, Economic Integration

\section{Introduction}

Modern regionalism dates back to the early 19th century, when several small European countries first established customs unions and then formed trade alliances with France, which had benefited from preferential access to the British market. When the multilateral trading system was established after World War II, a reflection on regionalism was embodied in the General Agreement on Tariffs and Trade (GATT), which authorized the creation of free trade areas and customs unions. Beginning with the Treaty of Rome, which created the European Community in 1958, many regional integration initiatives emerged in the 1950s and 1960s. Several of these initiatives disappeared without achieving their objectives. In particular, most regional initiatives between developing countries were no more than empty shells in terms of economic performance. With the exception of European integration projects, such as the European Economic Community (EEC) and the European Free Trade Association (EFTA), it is difficult to find examples of successful economic regionalism. Only a few supporters were convinced about the real positive effects of economic integration during the 1970s and 1980s.

However, economic regionalism reappeared in the mid-1990s and since then, it has spread to all developed and developing countries. Almost all of the countries have concluded or are negotiating Regional Trade Agreements (RTA). In fact, in July 2015, a total of 612 RTAs had been notified to the GATT or World Trade Organization (WTO) of which 406 were in force, according to the latter organization.

Economic regionalism has been primarily explained by domestic factors, such as economic benefits resulting from static and dynamic effects of economic integration in a regional context. This has led to studies of economic regionalism that focus on factors specific to each economic integration scheme. However, internal factors interact with external factors such as the development of multilateral trading systems and

${ }^{1}$ WTO website: https://www.wto.org/english/tratop_e/region_e/region_e.htm (accessed August 10, 2015). 
globalization. How do these external factors influence the development of regionalism? In order to answer this question, it is necessary to examine the development of regionalism in terms of both internal and external factors. This review also allows us to revisit and revise Balassa's typology of regionalism (Balassa 1961) since it does not reflect various aspects of regionalism, particularly under the new external circumstances that will be intensively discussed in this paper. All the more recent, the conventional typology of regionalism has been facing new challenges from the dynamics of regional trade architecture involving various countries such as the Trans-Pacific Partnership (TPP) and Regional Comprehensive Economic Partnership (RCEP). In this regard, this paper argues and provides new conceptual criteria that can be useful in classifying economic regionalism in a more detailed manner.

The remainder of this paper is as follows. The second section argues the terms that are frequently used in studies of economic integration and reviews its development from a historical perspective. The third section examines the typologies of economic integration schemes and their development. In addition, the limitations of these typologies will be discussed and relatively new typologies will be introduced. The fourth section discusses new and external factors, which should be included in studies on regionalism in order to better understand its various forms and provide a complementary conceptual framework of economic integration, which can be applied to current economic regionalism.

\section{Regional Economic Integration}

\section{A. Origin and definition}

Economic integration refers to both institutionalized economic structure established by regional agreements (regionalism) and the process/status of integration driven by trade and investments (regionalization). The term regionalism, of which its origins are found in international relations, refers to any form of institutionalized regional cooperation involving more than two countries. This elementary definition stems from the ordering pluralism concept (Delmas-Marty 1998) in which regionalism differs from multilateralism, especially in terms of the number of participating countries and the scope of rules (Ruggie 1992). This concept was rarely used in international economics, 
but since the 1980s, it has been increasingly used to such an extent that regionalism designates all forms of regional economic integration. It also appears as an establishment of RTAs at a practical level. ${ }^{2}$ Studies of regionalism were primarily based on European references. Until the early 1990s, the European Union (EU) had been regarded as a salient case of successful regionalism, considering its sustainability and effectiveness.

Distinguished from regionalism, the term regionalization refers to an intensification of trade and investments at an intra-regional level. The distinction between regionalism and regionalization comes from the studies on International Political Economics (IPE). ${ }^{3}$ An increasing awareness of regionalization is mainly due to the fact that in East Asia, economic integration has been based on regional division of labor and vertical Foreign Direct Investment (FDI) (Hugon 2003, Petit 2003). The main idea is that a de facto integration process may exist without regionalism. In fact, it is often at the intraregional level where trade and investments are the most dynamic (Gaulier et al. 2004). In order for economic integration to be successful, regionalism should facilitate ongoing regionalization. Regionalism also embodies an ongoing de facto integration trend in de jure form (Oman 1994). Furthermore, genuine regional economic integration is composed of both regionalism and regionalization, and a regional area can be regarded as economically integrated if and only if it includes a concentration of trade flows between countries as well as an institutionalized trade scheme based on binding and sustainable common rules (Figuiere et al. 2006).

\section{B. Regional trade agreement}

In the literature on economic integration, several terms are used to designate different forms of economic integration. Balassa's work (1961), which is considered as the most widely used reference, distinguishes economic integration schemes according to advances in integration. The first one is a Free Trade Agreement (FTA) (dismantlement of tariff and non-tariff barriers to trade), followed by the Customs Union (CU) (FTA + establishment of common external tariff), the Common Market (CU + free trade of services and free movement of production factors), and the Economic Union, which requires harmonizing economic policies and adopting common rules. Finally, the most advanced scheme is a

\footnotetext{
${ }^{2}$ The term regionalism may cause some confusion since most RTAs are concluded in a bilateral manner. Thus, strictly speaking, it should be referred to as bilateralism.

${ }^{3}$ For example, see Fishlow and Haggard (1992), Lorenz (1992), Haggard (1997) and Breslin and Higgott (2000).
} 
Monetary Union in which member countries adopt a common currency.

These different economic integration schemes are termed without distinction as RTAs by the WTO. This is due to the fact that the WTO defines RTAs as all forms of preferential trade agreements, which liberalize trade other than at the multilateral level. As Table 1 shows, most RTAs notified to the WTO are FTAs (85\%), while customs unions account for only $9 \%$, and partial scope agreements (among developing countries) represent $5.5 \%$ of all RTAs. These agreements are based on Article XXIV of the GATT, Article V of the GATS, and the Enabling Clause.

According to the WTO's classification, the majority of RTAs fall into one of two categories; namely, FTAs and CUs. ${ }^{5}$ However, RTAs are considerably disparate even within the same category. For example, the EU (notified to the WTO as a CU named European Community) has far exceeded the general perception of CUs. In addition, since the term RTA is rather simplistic and it disguises the differences among RTAs in several aspects, it is important to examine its typology in more detail.

\section{Table 1. List of all RTAs in force}

(as of July 2015)

\begin{tabular}{|c|c|c|c|c|c|c|c|}
\hline & $\begin{array}{c}\text { GATT } \\
\text { Article } \\
\text { XXIV }\end{array}$ & $\begin{array}{c}\text { Enabling } \\
\text { Clause }\end{array}$ & $\begin{array}{c}\text { GATS } \\
\text { Article } \\
\text { V }\end{array}$ & $\begin{array}{l}\text { GATT Art. XXIV } \\
+ \text { GATS Article V }\end{array}$ & $\begin{array}{c}\text { EC. + GATS } \\
\text { Article V }\end{array}$ & Total (\%) \\
\hline \multicolumn{2}{|c|}{ PSA } & & 15 & & & & $15(5.5 \%)$ \\
\hline \multirow[t]{2}{*}{ FTA } & FTA & 103 & 8 & & & & $111(40.5 \%)$ \\
\hline & EIA & & & & 119 & 3 & $122(44.5 \%)$ \\
\hline \multirow[t]{2}{*}{$\mathrm{CU}$} & $\mathrm{CU}$ & 11 & 6 & & & & $17(6.2 \%)$ \\
\hline & EIA & & & & 6 & 2 & $8(2.9 \%)$ \\
\hline \multicolumn{2}{|c|}{ EIA } & & & 1 & & & $1(0.4 \%)$ \\
\hline \multicolumn{2}{|c|}{ Total } & 114 & 29 & 1 & 125 & 5 & $274(100 \%)$ \\
\hline
\end{tabular}

(Note) PSA - Partial Scope Agreement; FTA - Free Trade Agreement; EIA - Economic Integration Agreement (Service agreement); CU - Customs Union. Some FTAs and CUs include service agreements, which also qualify them as EIAs.

(Source) WTO: http://rtais.wto.org/UI/PublicAllRTAList.aspx (Accessed July 15, 2015).

\footnotetext{
${ }^{4}$ The WTO provides an extremely wide definition of RTAs based on the following: 1) The definition of the WTO only concerns trade liberalization; and 2) It leaves open the question of why countries seek economic integration. For this argument, see Deblock (2005b).

${ }^{5}$ A Partial Scope Agreement (PSA) is a FTA of limited scale. Thus, it can be regarded as a FTA.
} 


\section{History of regional trade agreements}

Figure 1 shows the evolution of RTAs since the establishment of the GATT. The number of RTAs has been increasing, particularly since the early 1990s. It is possible to divide the development of RTAs into four distinct periods.

\section{Figure 1. Evolution of regional trade agreement in the world}

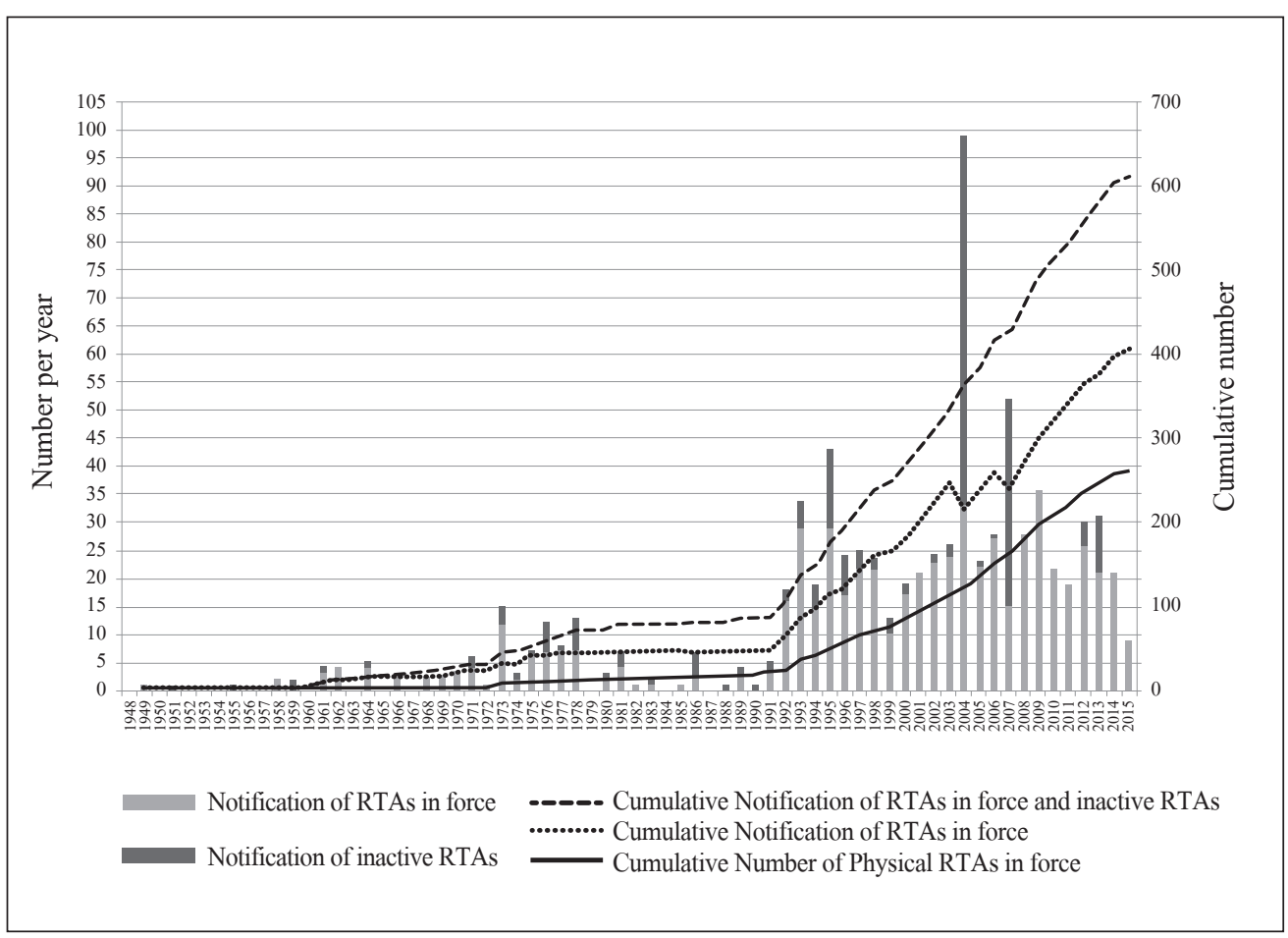

(Source) WTO: https://www.wto.org/english/tratop_e/region_e/regfac_e.htm (Accessed July 5, 2015).

The first period dates back to the late 1950s, when the EEC and the EFTA were established. Inspired by the European regionalism at the time, developing countries in Latin America and Africa initiated various regional integration projects that were later referred to as old regionalism. The second period, less distinctive than the first in terms of number of initiated RTAs, began in the second half of the 1980s. This period was marked by the development of two regional economic integrations, which were distinguished from previous ones: 1) the establishment of a single market in Europe by the Single European Act and the Treaty of Maastricht; and 2) the establishment of 
the North American Free Trade Area (NAFTA), which was the first RTA concluded between northern (United States and Canada) and southern countries (Mexico). Regionalism in Europe and North America had a significant impact on developing countries since European and North American countries were their main export markets.

In addition, the Mercado Comun del Sur (MERCOSUR) and the Association of South-East Asian Nations Free Trade Area (AFTA) were established in South America and Southeast Asia, respectively. The third period, which began in the mid-1990s, is characterized by the unprecedented proliferation of RTAs, as shown in Figure 1. Currently, most of the countries are covered by several RTAs for their trade. The most recent period can also be characterized by the emergence of plurilateral FTAs or socalled mega-FTAs, which involve a number of countries. The TPP, RCEP, and to a less extent, the Transatlantic Trade and Investment Partnership (TTIP) are the best examples in this regard. The last period is distinguished from the proliferation of bilateral FTAs in the third period since the plurilateral FTAs have been negotiated among the countries that have already constructed bilateral FTA networks with other countries. Furthermore, some of the mega-FTAs focus on regulatory convergence in trade and investment-related issues, which go far beyond tariff removals.

\section{Typologies of Regional Economic Integration}

\section{A. Typology of first generation}

The classification of the diverse forms of economic integration are usually based on Balassa's seminal work (1961), which provides the typology of economic integration according to advances in integration. 
Table 2. Balassa's typology

\begin{tabular}{|c|c|c|}
\hline $\begin{array}{l}\text { Forms of Economic } \\
\text { Integration }\end{array}$ & Definition & Examples \\
\hline $\begin{array}{l}\text { Free trade } \\
\text { agreement }\end{array}$ & $\begin{array}{l}\text { Member countries remove tariff barriers in } \\
\text { trade of goods within the free trade area. } \\
\text { However, each member maintains its own } \\
\text { tariff policy vis- } a \text {-vis the third country. }\end{array}$ & $\begin{array}{l}\text { - EFTA (established in 1960) } \\
\text { - AFTA (established in 1992) } \\
\text { - NAFTA (established in 1994) }\end{array}$ \\
\hline Customs union & $\begin{array}{l}\text { In addition to the free trade agreement, in } \\
\text { the customs union, member countries fix a } \\
\text { Common External Tariff (CET) vis- } a \text {-vis the } \\
\text { rest of the world }\end{array}$ & $\begin{array}{l}\text { - European Community since } 1968 \\
\text { - EU-Turkey Customs Union } \\
\text { since1996 }\end{array}$ \\
\hline Common market & $\begin{array}{l}\text { The common market consists of the } \\
\text { opening of all markets including service } \\
\text { and production factors (labor and capital } \\
\text { markets). However, its modality and } \\
\text { effective implementation are conditioned by } \\
\text { political and social regulations. }\end{array}$ & $\begin{array}{l}\text { - EC since } 1993 \text { (completion of } \\
\text { the single market) } \\
\text { - MERCOSUR and Andean } \\
\text { Community aims at establishing } \\
\text { a common market }\end{array}$ \\
\hline Economic union & $\begin{array}{l}\text { The economic union is characterized by } \\
\text { a certain level of harmonization regarding } \\
\text { economic policies. This is intended to abolish } \\
\text { all discrimination related to differences in } \\
\text { public policies among the member countries. }\end{array}$ & $\begin{array}{l}\text { - Current European Union } \\
\text { (not complete) }\end{array}$ \\
\hline Monetary union & $\begin{array}{l}\text { In a monetary union, member countries adopt } \\
\text { a common currency as well as harmonize } \\
\text { economic policies. }\end{array}$ & $\begin{array}{l}\text { - Euro Area ( } 19 \text { countries out } \\
\text { of } 28 \text { Member States of the EU) }\end{array}$ \\
\hline
\end{tabular}

In addition to the five types of economic integration, there are three types of trade arrangements, which are less advanced than FTAs. The first type is economic cooperation forums, which are rather loosely organized forums for cooperation between countries on specific issues such as trade, investments, and monetary policies. They are not RTAs based on binding treaties and obligations. The Asia Pacific Economic Cooperation (APEC) and the ASEAN Regional Forum are two examples. The second type is non-reciprocal preferential agreements, which are concluded between a developed country and a developing country. The former offers preferential access to its market to the latter without obtaining an equivalent concession. These agreements are not subject 
to the national treatment obligation of the GATT, only if trade preferences are granted to developing countries by developed countries. The Lomé Convention is an example. The third type is partial scope agreements, which do not cover substantial trade between member countries. Accounting for 5.5\% of the total number of active RTAs in 2015, these agreements are based on the Enabling Clause. Introduced in 1979, this clause allows partial tariff preferences between developing countries in a multilateral trading system.

Conceived during the early period of the economic integration in Europe, Balassa's typology was widely applied to the development of the EU. All of the predicted stages were largely respected. Beginning with completing a customs union in 1968, the EU has developed into the final stages of the typology; that is, a monetary union, by adopting the common currency. However, this typology has been losing its relevance in reference to economic integration. Regnault (2005) argues that it is hardly possible to separate one integration scheme from another since the relationship between financial and industrial capital has changed profoundly. Another criticism of Balassa's typology is that European experiences are not reproduced on other continents. An increasing number of RTAs around the world have, since the 1990s, not shown elements similar to those of the European integration, especially in terms of institutional framework and advances. Overall, Balassa's typology has become outdated based on the following context.

\section{Disparate RTAs}

A CU is supposed to achieve a higher level of integration than a FTA in Balassa's typology, since its member countries adopt a common external tariff, which involves a more difficult negotiation process. However, establishment of a CU does not mean that it has satisfied all of the obligations imposed upon a FTA. For example, quotas are supposed to be eliminated in a FTA, but in reality, they exist even in CUs. This observation raises a question about how to classify the different stages of integration in the typology. According to the typology, the RTA between the EU and Turkey is a CU, which is more advanced than a FTA (e.g., the NAFTA). However, the latter is often regarded as a more advanced economic integration, not only in terms of the actual trade and investment network, but also in regard to institutions (Regnault 2003), especially in the sense that the NAFTA includes the aspect of regulatory convergence (Regnault 2003). The NAFTA takes on several common market features, particularly in investment provisions. Post-NAFTA FTAs often include liberalization in fields other than trade, 
and they are more effective than the CUs concluded between developing countries in the 1990s.

\section{Paradigm changes in international trade}

In Balassa's typology, a FTA and CU only take into account the trade of goods. These integration schemes are based on the paradigm of international economies in which each country produces goods and trades them with others. However, in the context of globalization, a new paradigm has been emerging on the grounds that FDI and the production network of multinational firms play increasingly important roles in a regional context. Attracting more FDI is now often the most important reason for developing countries to seek RTAs, especially with developed countries in order to join the global value chain. This is based on the paradigm of the global economy. ${ }^{6}$ Balassa conceived his typology in the 1960s when the roles of FDI and cross-border production networks were less important. However, the motives of regional integration have been extended from the traditional area of trade into new areas, such as investments and regulations, which concerns deep integration.

\section{Increasing number of inter-regional RTAs}

The economic integration assumes that relatively close countries establish RTAs in order to facilitate intra-zone trade. Countries trade more intensively with their neighbors and thus, establishing RTAs can be a natural measure to strengthen natural trade flows. However, an increasing number of RTAs are interregional. In other words, they are concluded between geographically distant countries. The lack of geographical proximity makes it difficult to link these RTAs with regionalization. In addition, the proliferation of interregional RTAs makes any attempts to define a FTA as a regionally bounded trade scheme impossible.

\section{North-South RTAs}

Establishing RTAs implicitly assumes that the countries involved have similar levels of development. For example, the European countries were at relatively similar stages of development at the outset of their economic integration. In addition, the compensation

\footnotetext{
${ }^{6}$ Kebabdjian (2006) insists that regional integration schemes, as classified by Balassa, lie in the context where the division of national economies constitutes the fundamental principle in organizing the world economy: each nation must produce goods and exchange them with other nations. Current regionalization does not take place in an international context, but in the context of globalization.
} 
and assistance mechanism supported the integration of comparatively less developed countries and regions. However, since the 1990s, a number of RTAs have been concluded between countries that have different levels of development. The NAFTA is the first example. This type of RTA, called North-South RTAs, has been increasing since more developing countries are jumping on the RTA bandwagon. This is all the more remarkable since a significant number of these RTAs are interregional. From developing countries' perspectives, the main reasons for concluding North-South RTAs not only concern trade, but also FDI and economic reforms. ${ }^{7}$ Through RTAs with trade partners in the North, developing countries aim at strengthening their attractiveness as FDI destinations. As mentioned earlier, this new type of regionalism should be understood in light of the global economy paradigm rather than that of international economies.

\section{B. Second generations of typology}

The observations mentioned above allow us to consider other typologies of economic integration. RTAs are increasingly disparate, not only in terms of institutional advances, but also in regard to modus operandi or ideology. Given this problem, new complementary approaches appear to describe the situation at hand by focusing on the contents or features of the integration schemes. These approaches can be classified as either dichotomous or trichotomous typologies.

\section{Dichotomous typologies}

\section{1) De jure integration and de facto integration}

De jure integration refers to the establishment of RTAs based on institutionalized preferential trade regimes. However, RTAs differ not only in terms of progress in integration, but also in regard to their actual effectiveness. The latter is usually measured by intra-regional (RTA) trade shares. For example, intra-regional trade shares of the EU are more than 60\%, whereas those of the West African Economic and Monetary Union (UEMOA in French) are less than 10\%. De facto integration refers to regionalization

Regarding economic reforms of developing countries through regional economic integration (lock-in effects), see Fernandez (1997) and Blomstrom and Kokko (1997). 
driven by the intensification of trade and investments at a regional level. ${ }^{8}$ As Table 2 shows, intra-regional trade shares of regional groups are considerably different. Growing awareness of de facto regionalism is based on the fact that some regions (particularly, East Asia in the 1990s) have shown economic integration based on natural trade and investment flows without preferential trade regimes. This again raises the question regarding the effectiveness of regionalism. While many RTAs are not accompanied by de facto integration, some regions appear to be highly integrated without de jure integration.

${ }^{8}$ A term regional is used here in the literal sense, while its meaning in RTA becomes ambiguous. 
Table 3. Intra-group trade of services

(\%)

\begin{tabular}{|c|c|c|c|c|c|c|c|}
\hline & & 1970 & 1980 & 1990 & 1995 & 2000 & 2003 \\
\hline \multirow{5}{*}{$\begin{array}{l}\text { RTAs or regional } \\
\text { grouping, including } \\
\text { higher-income } \\
\text { countries }\end{array}$} & APEC & 36 & 33.7 & 39 & 46.3 & 48.5 & 44.5 \\
\hline & Euro-Mediterranean & 43 & 39.4 & 42.2 & 37.7 & 37.6 & 40.6 \\
\hline & EU-15 & 45.6 & 41 & 44 & 39.7 & 35.9 & 38.7 \\
\hline & EFTA-4 & 0.9 & 0.5 & 0.5 & 0.4 & 0.4 & 0.4 \\
\hline & NAFTA & 21.7 & 16.6 & 16.2 & 16.8 & 19 & 15.5 \\
\hline \multirow{6}{*}{$\begin{array}{l}\text { Central and } \\
\text { South America }\end{array}$} & ACS & 2.8 & 3.1 & 1.9 & 2.6 & 3.9 & 3.3 \\
\hline & Andean Group & 1.9 & 1.7 & 0.9 & 0.8 & 0.9 & 0.8 \\
\hline & $\mathrm{CACM}$ & 0.4 & 0.3 & 0.1 & 0.1 & 0.3 & 0.3 \\
\hline & CARICOM & 0.4 & 0.6 & 0.2 & 0.1 & 0.1 & 0.2 \\
\hline & LAIA (ALADI) & 4.5 & 4.4 & 3.4 & 4.1 & 5.3 & 4.7 \\
\hline & MERCOSUR & 1.7 & 1.6 & 1.4 & 1.4 & 1.4 & 1.4 \\
\hline \multirow{6}{*}{$\begin{array}{l}\text { Asia and } \\
\text { Middle East }\end{array}$} & Arab Common Market & 1.7 & 1.5 & 1 & 0.4 & 0.7 & 0.6 \\
\hline & ASEAN & 2.3 & 3.9 & 4.3 & 6.4 & 6.7 & 6.1 \\
\hline & GAFTA & 3 & 10.3 & 3.8 & 2.6 & 3.5 & 3.4 \\
\hline & GCC & 1.9 & 8.5 & 2.5 & 2 & 2.6 & 2.5 \\
\hline & SAARC & 1.1 & 0.7 & 0.8 & 0.9 & 1 & 1.1 \\
\hline & UMA & 1.5 & 2.3 & 1 & 0.6 & 0.7 & 0.8 \\
\hline \multirow{9}{*}{ Africa } & CEMAC & 0.2 & 0.3 & 0.2 & 0.1 & 0.2 & 0.2 \\
\hline & CEPGL & 0.3 & 0.1 & 0 & 0 & 0 & 0 \\
\hline & COMESA & 1.6 & 0.6 & 0.4 & 0.4 & 0.4 & 0.4 \\
\hline & EAC & 0.3 & 0.1 & 0.1 & 0.1 & 0 & 0.1 \\
\hline & ECCAS & 0.6 & 0.3 & 0.3 & 0.2 & 0.3 & 0.3 \\
\hline & ECOWAS & 1.1 & 0.4 & 0.6 & 0.4 & 0.6 & 0.5 \\
\hline & SADC & 2.2 & 1.6 & 1 & 0.8 & 0.6 & 0.7 \\
\hline & UDEAC & 0.2 & 0.3 & 0.2 & 0.1 & 0.2 & 0.2 \\
\hline & UEMOA & 0.3 & 0.3 & 0.1 & $? 0.1$ & 0.1 & 0.1 \\
\hline
\end{tabular}

(Notes) (i) Trade of services is excluded from intra-group trade shares.

(ii) For official full name of RTAs and regional trading blocs, see the Appendix.

(iii) Trade of services is excluded from intra-zone trade shares.

(Source) World Development Indicator 2005 - The World Bank. 


\section{2) Closed and open regionalism}

The distinction between closed and open regionalism is based on two opposing concepts of regionalism, which are ambiguous in practice. Closed regionalism (vis- $a$ vis the rest of the world) refers to the wave of regional integration projects initiated by developing countries in Latin America and Africa during the 1960s, as summarized in Table 3. At that time, developing countries did not have large domestic markets to support their industrial development. In light of this limitation, the Economic Commission for Latin America and the Caribbean (ECLAC) advanced the idea of initiating regional integration projects between developing countries. ${ }^{9}$ Their regional integration was characterized by substituting imports with regionally produced goods. Given that each national market was not large enough, the integration of national markets at the regional level was regarded as a viable option in order to reach the minimum efficient scale of production. However, at the basis of this integration was the concept of import substitution industrialization, which resulted in the concerned market breaking off from the international market. This phenomenon is known as closed regionalism. ${ }^{10}$

These regional integration projects were not successful in producing the anticipated results. In particular, they revealed the following problems. First, their preferential trade liberalizations covered only a limited number of products and hence, actual trade effects were small. Second, as a result of substituting imports with regionally produced products, less industrialized countries often ended up supporting inefficient industries of relatively more industrialized neighbors (Agarwal 1989). Finally, when their preferential liberalization could weaken the position of protected industries, oligopolies (whose vested interest had been politically rooted) and their negotiations were often delayed or unable to reach a final deal.

\footnotetext{
${ }^{9}$ The ECLAC was established in 1948 by proposition of Chile to the Social and Economic Council of the United Nations. From its beginning, the Commission raised issues of cooperation between Latin American countries. It proposed strongly that countries would cooperate in order to enlarge their market on a reciprocal basis and to have collectively stronger negotiation power in the international economic scene. It took a time that its recommendation found a momentum as viable plan. The establishment of the EEC in 1957 served as example, exerting a demonstration effect on projects recommended by the ECLAC and incited Latin American countries to move toward creation of large regional common market (Kaiser 1967, Santa Cruz 1996).

${ }^{10}$ Closed regionalism designates the old regionalism. However, in a general way, open regionalism is clearly different from the new regionalism, as we specify in this section.
} 
Table 4. RTAs in Latin America and Africa during the period of closed regionalism

\begin{tabular}{|c|c|c|c|}
\hline Continent & $\begin{array}{c}\text { RTAs } \\
\text { (Year of foundation) }\end{array}$ & $\begin{array}{c}\text { Member States } \\
\text { (The latest membership) }\end{array}$ & Development \\
\hline \multirow{4}{*}{ Africa } & $\begin{array}{l}\text { Customs Union of } \\
\text { Equatorial Africa (1959) }\end{array}$ & $\begin{array}{l}\text { Central, Chad, Congo, Gabon, } \\
\text { and Cameroun }\end{array}$ & $\begin{array}{l}\text { Reorganized in } 1964 \text { by } \\
\text { the Customs and Economic } \\
\text { Union of Central Africa } \\
\text { (UDEAC in French) }\end{array}$ \\
\hline & $\begin{array}{l}\text { Customs Union of West } \\
\text { African States (1959) }\end{array}$ & & $\begin{array}{l}\text { Became the West African } \\
\text { Economic Community } \\
\text { (CEAO in French) in } 1970\end{array}$ \\
\hline & $\begin{array}{l}\text { Economic Community } \\
\text { of West African States }\end{array}$ & $\begin{array}{l}\text { Benin, Burkina Faso, Cote d'Ivoire, } \\
\text { Guinea Bissau, Mali, }\end{array}$ & \\
\hline & $\begin{array}{l}\text { (ECOWAS/CEDEAO) } \\
(1974)\end{array}$ & $\begin{array}{l}\text { Niger, Senegal, Togo, } \\
\text { Cape Verde, Gambia, Ghana, } \\
\text { la Guinea, Liberia, Nigeria, } \\
\text { and Sierra Leone }\end{array}$ & \\
\hline \multirow{4}{*}{$\begin{array}{c}\text { Latin } \\
\text { America }\end{array}$} & $\begin{array}{l}\text { Latin American } \\
\text { Free Trade Association } \\
\text { (LAFTA) (1960) }\end{array}$ & $\begin{array}{l}\text { Argentina, Brazil, Chili, Mexico, } \\
\text { Paraguay, Peru, and Uruguay }\end{array}$ & $\begin{array}{l}\text { Replaced by the Latin } \\
\text { American Integration } \\
\text { Association in } 1981\end{array}$ \\
\hline & $\begin{array}{l}\text { Central American } \\
\text { Free Trade Area (1958) }\end{array}$ & $\begin{array}{l}\text { Guatemala, El Salvador, } \\
\text { Honduras, and Nicaragua }\end{array}$ & $\begin{array}{l}\text { Became the Central American } \\
\text { Common Market in } 1960\end{array}$ \\
\hline & $\begin{array}{l}\text { Caribbean } \\
\text { Free Trade Area } \\
(1967)\end{array}$ & $\begin{array}{l}\text { Antigua-et-Barbuda, Bahamas, } \\
\text { Barbados, Belize, Dominique, } \\
\text { Grenada, Guyana, Haiti, Jamaica, } \\
\text { Montserrat, Saint Lucia, Saint Kitts } \\
\text { and Nevis, Saint Vincent and } \\
\text { the Grenadines, Surinam, } \\
\text { and Trinidad and Tobago }\end{array}$ & $\begin{array}{l}\text { Became the Caribbean } \\
\text { Community and Common } \\
\text { Market (CARICOM) in } 1973\end{array}$ \\
\hline & $\begin{array}{l}\text { Andean Group } \\
\text { (1969) }\end{array}$ & $\begin{array}{l}\text { Bolivia, Colombia, Ecuador, } \\
\text { Peru, and Venezuela }\end{array}$ & $\begin{array}{l}\text { Became the Andean } \\
\text { Community of Nations } \\
\text { (CAN in Spanish) in } 1997\end{array}$ \\
\hline
\end{tabular}

While closed regionalism was well explored in conceptual discussions, its opposite, open regionalism was unclear. At its core, the term regionalism implies a discriminatory characteristic due to the existence of tariff preferences between members. In this sense, 
the term open can hardly be unified with the term regionalism. Open regionalism was intensively discussed in the mid-1990s among trade economists in the US and East Asia. According to Bergsten (1994, 1997), open regionalism should include at least one of the following three features: 1) A trading bloc created under open regionalism should be open about its membership. If this trading bloc is attractive, then it will lead to the creation of an open free trade area between open economies; 2) Whereas former integration models were closed and driven by public authorities, integration in open regionalism should be market friendly. This means that members should respect the Most Favored Nation (MFN) clause through their liberalization; and 3) Open regionalism is characterized by intergovernmental cooperation, which implies the principle of consensus for decision-making. By respecting each member's rights, it should contribute to resolving problems related to common interests and the convergence of public policies around a given model.

Similar definitions can be found in a number of studies in the mid-1990s (Council of Economic Advisors 1995). However, they define neither trade liberalization modalities nor the scope of trade liberalization. The ambiguous definition of open regionalism would place all other regional economic integrations into the category of closed regionalism. ${ }^{11}$ According to its definition, customs unions do not find their place since members of such unions cannot pursue trade liberalization on a unilateral basis.

In fact, open regionalism, as defined by Bergsten, describes the APEC that is neither based on treaties nor on binding obligations (Webber 2001). As such, the APEC does not constitute regional trade agreements and it does not represent characteristics of regionalism. In this regard, Deblock (2005a) traces the emergence of this concept back to the late $1980 \mathrm{~s} .^{12}$ He argues that the conceptual rise of open regionalism has its origin in the protection of a multilateral trading system. An increasing number of RTAs may divide a multilateral trading system into fragmented trading blocs, which suggests that regionalism may be a stumbling block toward multilateralism.

\footnotetext{
${ }^{11}$ For criticisms on the open regionalism (Panagariya 1999).

${ }^{12}$ According to Deblock, three major realities in the world economy should be considered: 1) reconfiguration of the world economy centered on the three economic poles - North America, Europe and East Asia; 2) competition between different alternatives of market economy-Anglo-Saxon, Continental European and State developmental models; and 3) new types of economic alliances which replace old types of alliances based on security issues during the Cold War period. From the observation of these three realities, it has been increasingly important to prevent the proliferation of RTAs from leading to a division of the world into competing, fragmented trading blocs. If this situation occurs, it would not only be against US interests, but also against development of the multilateral trading system which has enabled trade and investment liberalization. From an American perspective, one possible way to prevent this situation is to provide a new concept of regionalism - open regionalism - and to participate actively in it.
} 


\section{3) Shallow integration and deep integration}

The distinction between shallow and deep integration is also based on opposing features of two types of integration. ${ }^{13}$ Shallow integration refers to RTAs that merely concern the dismantlement of tariff barriers, which includes partial scope agreements. The Euro-Mediterranean Partnership (Euromed) is an example. All articles in the agreement, with the exception of those related to trade liberalization, are devoid of concrete commitments and confined to the declaration of intentions. Most RTAs concluded between developing countries before the 1990s tended to be of a shallow integration nature. As opposed to shallow integration, deep integration means establishing far-reaching RTAs that go beyond trade liberalization. In particular, it concerns trade of services, investments, competition, and public procurement, whilst taking on some features of a common market and focusing on regulatory issues. The EU is the most advanced example of deep integration. NAFTA is also an example, which is all the more symbolic since it is the first North-South integration scheme. Chapter XI of the NAFTA agreement stipulates provisions on investments and dispute settlements, which require a certain level of harmonization of legal standards amongst member states. Given that both Euromed and NAFTA are FTAs, the distinction of shallow/deep integration reveals that RTAs (either FTAs or CUs) can be considerably different in terms of effectiveness and scope.

\section{Trichotomous typology}

Deblock et al. (2003) proposes a new typology inspired by Mundell's triangle of incompatibility. At each angular point of the triangle, they place a feature of possible regionalism: 1) market autonomy (pro-market); 2) sovereignty of Member States; and 3) institutionalized cooperation between Member States. In this relation schematized in Figure 2, economic regionalism takes on only two of the three features, which allows one to identify the following three types of regionalism: 1) Regulation and sanction regionalism based on market autonomy and institutionalized cooperation between Member States, which is characterized by rules of law and supranational institutions. The European integration is one example; 2) Risk management regionalism based on market autonomy and a respect of Member States' sovereignty, which includes a code

\footnotetext{
${ }^{13}$ Instead of using the term regionalism (cf. shallow regionalism and deep regionalism), we use the term integration, as it is shallow integration and deep integration that are usually used in the related literature.
} 
of conduct and dispute settlement mechanism. NAFTA is a possible example; and 3) Regulated markets and organized trade regionalism, which reconciles the respect of Member States' sovereignty and institutionalized cooperation at the expense of market freedom. No example currently exists, but the former Soviet bloc was of this type.

\section{Figure 2. Trichotomous typology}

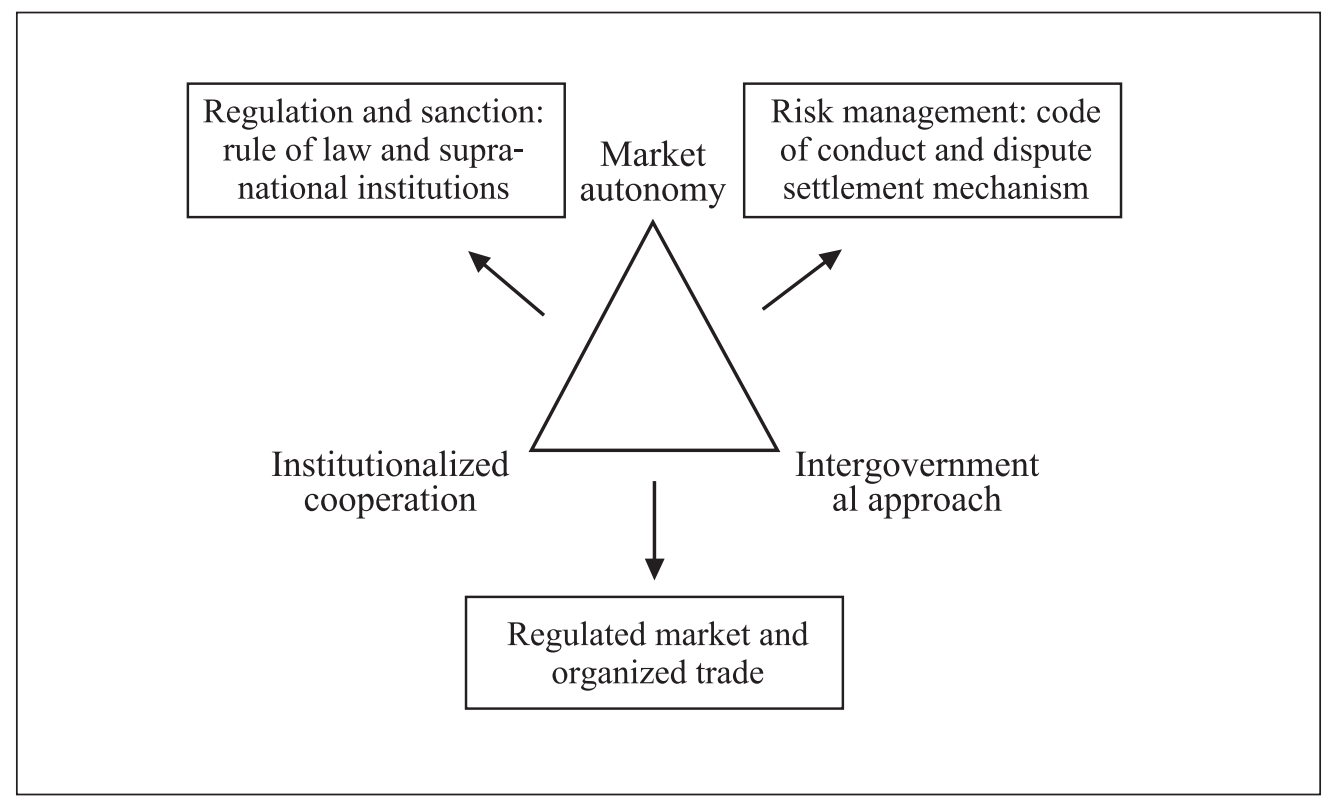

(Note) Kebabdjian(2002) proposes a simple variant of this typology while changing the following:

1) Regulation and sanctionis replaced by pure European model;

2) Regulated market and organized trade is replaced by regional governance; and

3) Risk management is replaced by pure regional regime.

(Source) Deblock (2004).

Regnault (2005) argues that this typology brings original elements into the studies of regionalism, particularly in the sense that it includes deep integration. However, he criticizes that the typology lacks the following two considerations. First, it does not question the proper notion of region. In this regard, establishing a RTA does not mean that its member countries form a region, particularly in the case of interregional RTAs. Second, this typology does not consider an increasing number of North-South RTAs, whereas its importance has been increasing in the studies of regionalism.

It is possible to add three remarks. First, this typology does not consider the relationship between RTAs and multilateral trading systems (regionalism vs. multilateralism). In 
fact, RTAs are closely related to the development of multilateralism and it is necessary to understand how the multilateral trading system influences RTAs. In the same manner, the typology does not suggest how globalization and regionalization are interrelated. Given that regionalization is a vector of globalization, the latter influences the diffusion of RTAs. Finally, while the typology characterizes each RTA, one country can actually have multiple RTAs with different trading partners. This suggests that RTAs are interactive and influenced by the establishment of other RTAs. These remarks lead us to consider other factors that influence the characteristics of RTAs.

\section{New Factors Differentiating Regional Economic Integration}

Economic regionalism is influenced by external factors such as advances in the multilateral trading system, globalization, and emerging competitive RTAs. These factors appear to be different according to each period concerned, which leads to the following question: Do RTAs concluded in the 2000s have the same characteristics as those established in the past?

\section{A. External factors}

\section{Interaction between regionalism and multilateralism}

Debates on the relationship between multilateralism and regionalism are summarized with the help of two key questions. The first much debated question is whether preferential trade liberalization with RTAs contributes to strengthening the multilateral trading system as an integral part (i.e., a stepping stone) or whether it hinders efforts to make progress in multilateral trade liberalization (i.e., a stumbling block). Since the 1990s, this question has divided economists into two groups: one in favor of RTAs (led by Summers) and the other skeptical about RTAs (led by Bhagwati). ${ }^{14}$ The latter group

\footnotetext{
${ }^{14}$ On one hand, economists such as Bhagwati (1995), Panagariya (1999) and Krueger (1993) criticize negative effects of RTA, especially adverse effects of RTAs on the multilateral trading system. On the other hand, a different group of economists including Summers (1991), Lawrence (1996), Baldwin (1995) and Ethier (1998) focus on the positive effects of RTAs on economies concerned.
} 
criticizes that preferential trade liberalization is inferior to multilateral liberalization and it is concerned about negative effects related to the proliferation of RTAs on the multilateral trading system.

The second and less contentious question is how the development of multilateral trading systems influences proliferation of RTAs. This question concerns both developed and developing countries and it is closely related to preference margins of RTAs. It also begins with a speculative hypothesis: If multilateral trade liberalization brought about satisfactory results to countries, then it would reduce the desire of countries to turn to regionalism. However, a delay and impasse in multilateral trade negotiations can give rise to increasing preferences for RTAs.

\section{Figure 3. Preference margin of RTAs}

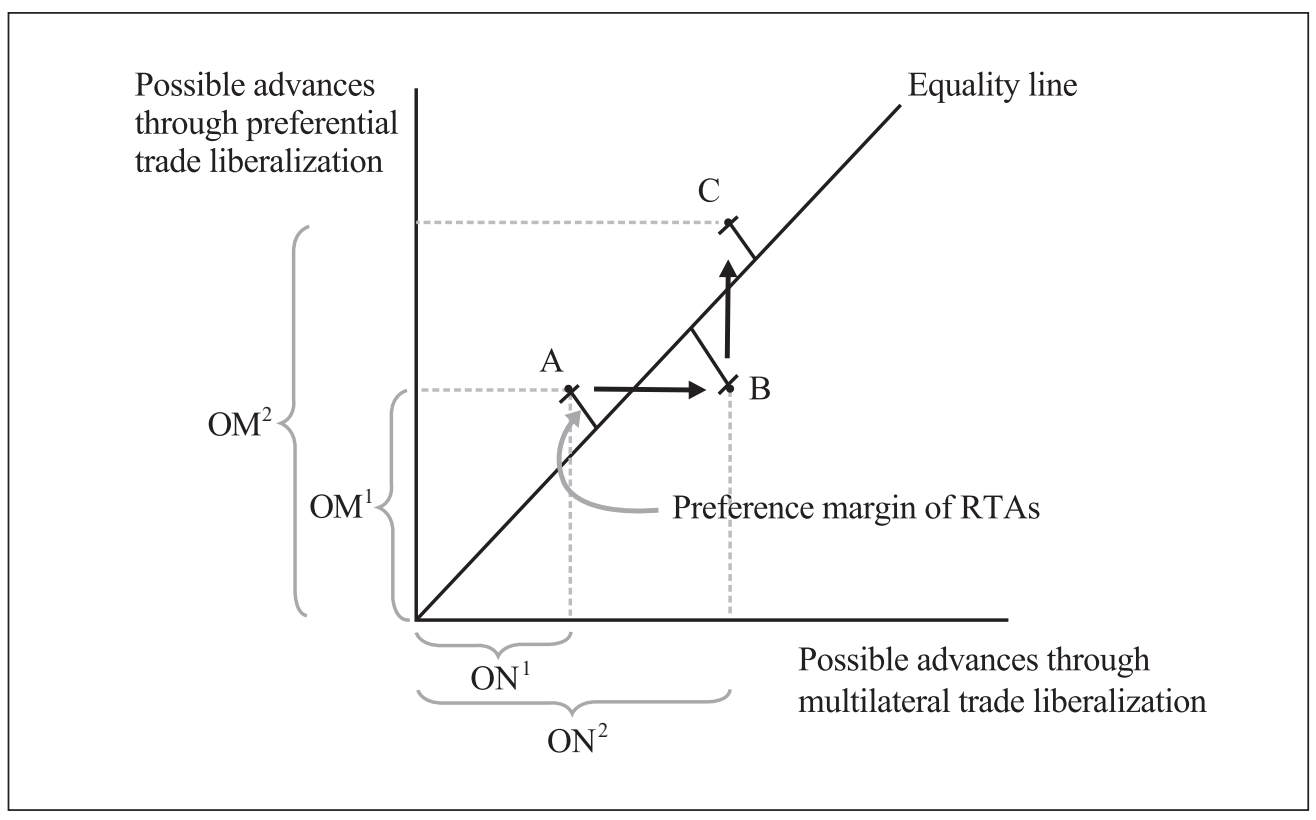

(Note) The term advances refers to the possibility of achieving the objectives of each country.

According to Figure 3, which illustrates the preference margin of RTAs, a country initially has a net preference margin at balance point $A$. This is because possible advances through preferential liberalization are more important than those reached through multilateral liberalization. However, as multilateral negotiations produce satisfactory results for countries, the preference margin of RTAs reduces and even becomes negative 
(shift of the balance point from point $A$ to point $B$ ). The country now prefers to adhere to multilateralism. However, suppose that multilateral negotiations reach an impasse, whereas establishing RTAs appears to provide a possible route to attaining trade-related goals, which would possibly be attained through multilateral liberalization. Then, the balance point shifts from point $B$ to point $C$, which once again creates a net preference margin of RTAs.

Keeping in mind a rather competitive relationship between regionalism and multilateralism, it is useful to ask two questions. First, how can the development of multilateralism dissuade countries from inclining to regionalism? And second, how can the establishment of RTAs be regarded as an alternative option to efforts on multilateral trade liberalization?

Since the establishment of the GATT in 1948, eight rounds of multilateral trade negotiations have succeeded in reducing tariffs. The tariff cuts on industrial products have been more important in developed countries. Since the Kennedy Round, which included anti-dumping issues in its negotiation agenda, the GATT/WTO has branched out its issues to various areas such as trade of services, dispute settlements, and intellectual property rights. Given that tariffs of developed countries are considerably low regarding industrial products, these issues have grown in their importance. As multilateral liberalization advances and produces more effective and far-reaching results, both the existing and forthcoming preference margins of RTAs are supposed to be eroded. This might have been true until the late 1980s, especially since the increase in the number of RTAs was relatively small. However, since the early 1990s, the number of RTAs has been rapidly increasing. Is this related to delay in multilateral trade negotiations? What has driven countries into rushing toward regionalism? A simple and immediate answer is that the number of parties involved in RTA negotiations is smaller and thus, it takes less time to reach a decision (Schott 1989). This is often why RTAs are attractive to policy makers and business communities who want fast results. In the following, three more arguments are presented.

First, as various issues are negotiated in the GATT/WTO, RTAs, especially those of developed countries tend to include these issues in their preferential liberalization agenda. Recent RTAs described as WTO plus take on characteristics of deep integration by focusing on issues such as trade of services, investments, competition, intellectual property, and public procurement. ${ }^{15}$ If the multilateral negotiations are delayed or they

\footnotetext{
${ }^{15}$ In the hypothesis that countries attempt to achieve trade liberalization by establishing RTAs which are impossible in a multilateral framework, RTAs always include more advanced elements than what countries can obtain in the multilateral trading system.
} 
seem to be insufficient to produce an effective liberalization, then countries can turn to preferential liberalization with like-minded countries.

Second, developed countries have had increasing recourse to non-tariff barriers such as anti-dumping and safeguard measures as well as voluntary export restrictions. At the same time, developing countries have lowered their MFN tariffs (Lal 1993). Facing effective increases in non-tariff-related protectionism, multilateral trading systems do not guarantee developing countries access to the markets of developed countries. From the perspective of developing countries, establishing RTAs with developed countries can allow them to secure market access.

Finally, it is important to note that the attitude of the US toward RTAs changed considerably in the late 1980s. Poor progress in the multilateral negotiations has led the US to seek a regional approach that allows it to achieve its goals in an easier and faster way (Panagariya 1999). Some argue that the EU started pushing for internal liberalization in order to complete a single market in the mid-1980s, and this shifted European efforts from multilateral trade issues to regional integration.

\section{Influence of globalization}

Another external factor is the globalization of economies. Globalization is closely related to the emergence of a new type of regionalism and the regionalization of economies in the 1990s. The globalization changed the trade paradigm from an international one to a global one (Kebabdjian 2006). This observation raises the question of how globalization affects economic integration. There are three possible answers for this question.

The first answer concerns regionalization. When globalization is defined as increasing trade and the mobility of production factors, which makes economies more interdependent, it is natural that it is more visible in a regional context, since geographic distance still plays an important role. An empirical observation of trade flows reveals that international trade is regionally biased (Gaulier et al. 2004). In this sense, the regionalization of economies is one of the globalization vectors and it can be considered

\footnotetext{
${ }^{16}$ However, two facts support opposing arguments on policy changes of the US and the EU towards regionalism: Firstly, negotiations of FTA between the US and Canada started one year ahead of the Uruguay Round, which suggests that the US started using RTAs before the period of impasse in multilateral negotiations. Secondly, the single market project of the EEC was prepared also before the period of the Uruguay Round. In the mid-1980s, intra-regional (RTA) trade shares in the world trade, excluding intra-European trade, accounted for only $8.5 \%$. This suggests that most trade was inter-regional in the multilateral trading system (Bhagwati 1995).
} 
as the first phase of globalization (Deblock 2005). ${ }^{17}$

The second reflective answer is that globalization changed the traditional transmission channel of economic integration, which had been centered on trade. The theory of customs unions assumed international trade between countries; that is, economic integration occurred through trade. However, globalization has extended this channel to production factors, especially capital investment. Thus, it is necessary to conceive a new form of economic integration based on the production networks of FDI and MNF. European experiences provide ample examples in this regard. In the context of the increasing mobility of FDI in the 1970s, EEC member countries succeeded in attracting massive American and eventually Japanese FDI in light of the development of a common market in Europe (Winters 1993). The Irish experience in the 1990s is the most remarkable example in that European economic integration was one of the main reasons for the small economy's success in attracting a considerable amount of FDI.

Closely related to the second answer, the final one is that globalization contributes to a rise in North-South RTAs. In general, developed countries have relatively open trade structures with low tariff levels, whereas developing countries have relatively protective trade structures. When a developed country and developing country establish a RTA, the latter is obliged to make more significant concessions to the former. The developing country's preference margin to a RTA in terms of tariffs, compared with that of its northern trade partners, is low. However, the most important issue in North-South integration is not trade-related, but concerns attracting more FDI. ${ }^{18}$

\section{Interaction between RTAs}

In the context of the development of multiple RTAs in the same period, it is necessary to consider the interactions between them. The argument begins with the observation that RTAs or national economies are competitive in nature.

\section{1) Threat and demonstration effects}

Questions regarding the interaction between RTAs as sub-regional systems were

\footnotetext{
${ }^{17}$ However, certain authors call into question the idea of regionalized global economy and argue in favor of transnationalization of economies organized at global level. For this argument, see Castells (1998).

${ }^{18}$ Focusing on motives of North-South integration, Ethier (1998) summarizes stylized facts. He points out that developing countries seek to host more FDI by establishing FTAs with developed countries. In addition, these FTAs can make signal effects to preferential access to developed countries' markets, suggesting credible commitment to market economy based principles. This can be regarded as the establishment of a secured system, which contributes to reducing uncertainty from the point of view of investors.
} 
initially raised in studies on international relations. A key issue was whether a subregional system incites excluded countries to create their own sub-regional system. The speculative answer has been yes based on the following conditions (Kaiser 1968): 1) When the sub-regional system may affect interests of excluded countries (threat effect) or 2) When it seems to be relevant as a model to other countries (demonstration effect).

European experiences in the 1960s provide an example of the first case. The establishment of the EFTA was largely motivated by concerns about the emerging EEC and its discriminatory effect on excluded countries. The EFTA completed internal trade liberalization earlier than the EEC in order to counteract the discriminatory effects of establishing a customs union in the EEC (Curzon 1974, Baldwin 1994). The establishment of the Latin American Free Trade Area (LAFTA) in the 1960s can be explained by the demonstration effect. The EEC is an example of successful integration, which allows Latin American countries to cooperate and increase their voice in international politics.

However, if a regional sub-system is attractive and open to membership, then it can undermine other regional sub-systems. Again, an example can be found in the relationship between the EEC and the EFTA. The latter expanded to the United Kingdom, Denmark, and Ireland, while the EFTA contracted. Meanwhile, the EEC seemed to be attractive to the EFTA members and it was sufficiently open to the EEC's membership.

\section{2) Hub and spoke regionalism}

The argument of hub and spoke regionalism explains the proliferation of RTAs. The term hub represents a country that has multiple RTAs with its trade partners, while the term spoke refers to a country that is linked to its partners only through the hub. ${ }^{19}$ In contrast to the hub, the spoke is disadvantaged in terms of market access, which reduces its attractiveness as an FDI location. Separation between the spokes makes all of the dynamic effects mainly resulting from market expansion, difficult. In addition, once a hub and spoke system is created, with a concentration of investments and production in the hub, it is difficult for a spoke to catch up with the hub and redirect the FDI towards itself. The only way to get out of this situation is by establishing RTAs with other spokes. However, the disadvantages temporarily induced by the situation of spokes have longlasting consequences (Baldwin 1994). Aversion to the spoke situation creates a domino

\footnotetext{
${ }^{19}$ For a more detailed analysis (Baldwin 1995).
} 
effect and it shows that the proliferation of RTAs is self-reinforcing. Furthermore, it is noteworthy that the emergence of large trading blocs, such as the EU and NAFTA in the early 1990s, had other countries worry about marginalization in these important markets.

\section{B. Number of participants}

Most regionalisms, especially since the 1990 s, actually appear as bilateral RTAs, while regionalism often refers to all forms of preferential liberalization regimes. Yet, these RTAs are not necessarily concluded between neighboring countries, which makes the term regional obsolete in RTAs. RTA is a broad term that includes all types of preferential trade agreements regardless of the number of participants. It does not distinguish between plurilateral and purely bilateral agreements. It is possible to divide these RTAs into three groups in terms of number of participants. The first group consists of RTAs that concern more than two countries, which are referred to as plurilateral trade agreements, according to the WTO. The second group refers to RTAs between institutionalized trading blocs constituted by plurilateral agreements and one single country, which result in a bilateral format. The latter is interested in becoming an integral or privileged part of the former in order to obtain better market access and more FDI. In this sense, these RTAs can be referred to as gravitational agreements. The last group represents RTAs concluded between two countries or otherwise referred to as bilateral ones.

\section{Plurilateral trade agreements}

Plurilateral trade agreements include more than two countries. The EU, MERCOSUR, and to a certain extent, NAFTA fall into this group of RTAs. They used to be initiated among neighboring countries, while more recent ones, such as the TPP, involve geographically remote countries. In this sense, this type of RTA can be divided into two groups, according to the period of development and membership. The first type of plurilateral agreement, which dates back before the 2000s, mainly involve geographically close countries. The EU is a notable example and to a less extent, MERCOSUR and AFTA fall into this type of agreement. They are geographically more selective and they aim to create a regional market, often more far-reaching than trade liberalization.

The second type of plurilateral FTAs are those that have appeared very recently, 
such as the TPP and the RCEP. They differ from other RTAs in the following features. First, they are negotiated by geographically remote countries, which have been involved in multiple bilateral trade agreements. For example, all member countries in the TPP negotiation process have formed multiple RTAs with other partners, some of which have already formed bilateral FTAs with other members of the TPP. For example, Singapore has RTA status with all members of the TTP. In this sense, negotiating a mega-RTA is an attempt to place all of the existing bilateral FTAs into one envelope, thus removing the spaghetti bowl effect. Second, these RTAs involve both developed and developing countries, and they take on the feature of North-South integration. Given that the latter tends to require the South partner to adopt a wide range of regulatory reforms, it is expected that a regulatory convergence becomes an important objective of the trade negotiation. Third, recent plurilateral RTAs generally do not seek to create a regional identity between member countries. It is more difficult for such different countries to pursue any type of regional identity or common stance in international issues. In this sense, joining the mega-RTAs is a part of commercial policy rather than politically motivated regional integration.

\section{Gravitational trade agreements}

Gravitational trade agreements involve two parties: an existing trade bloc constituted by a RTA which is already a large integrated market and a single country. In general, the former is the principal trade partner of the latter and it has multiple RTAs with developing countries. Through these agreements, the trade bloc aims at strengthening its position as a regional trade hub, while the developing countries are interested in obtaining better market access and in improving their attractiveness as a FDI location. The multiple RTAs built around the EU provide examples in this regard. 
Table 5. The EU's RTA Structure

\begin{tabular}{|c|c|}
\hline The EU's RTA Structure & Signatories of the EU's RTAs \\
\hline 1. European union & - 28 Member States \\
\hline 2. European economic area & $\begin{array}{l}\text { - Member States of the EFTA : Norway, Iceland, } \\
\text { and Liechtenstein } \\
\text { - Switzerland has a separate FTA with the EU }\end{array}$ \\
\hline 3. Customs union & Turkey, Andorra, and San Marino \\
\hline 4. Free trade agreement & $\begin{array}{l}\text { European Agreements: Central and Eastern } \\
\text { European countries before their accession to the EU } \\
\text { - Euro-Mediterranean Association Agreements: } \\
\text { Algeria, Egypt, Israel, Jordan, Lebanon, Morocco, } \\
\text { Syria, and Tunisia (Barcelona Process) } \\
\text { - Stabilization and Association Agreement: } \\
\text { Macedonia and Croatia } \\
\text { - Bilateral FTA (EU and one signatory): Switzerland, } \\
\text { Mexico, Chile, South Africa, and Korea }\end{array}$ \\
\hline $\begin{array}{l}\text { 5. Non-reciprocal trade } \\
\text { preferences }\end{array}$ & $\begin{array}{l}\text { - } 80 \text { countries located in the ACP } \\
\text { (Africa, Caribbean, and Pacific) }\end{array}$ \\
\hline $\begin{array}{l}\text { 6. Non-reciprocal autonomous } \\
\text { trade preferences }\end{array}$ & $\begin{array}{l}\text { - States of the Commonwealth of Independent States } \\
\text { (CIS), the Balkan countries }\end{array}$ \\
\hline
\end{tabular}

(Source) Author's modification based on Sapir (1998).

Among the multiple layers of the EU's RTAs, as shown in Table 5, the fourth category can be regarded as gravitational trade agreements, especially if reciprocity is considered as a condition of authentic RTAs. Given the size of the US market in the NAFTA, the bilateral FTAs of the US with developing countries can be regarded as gravitational, although its agreements are purely bilateral agreements. ${ }^{20}$

\footnotetext{
${ }^{20}$ These trade agreements should be analyzed in consideration of motives of the US and the EU. Policy changes of the US are noteworthy. Increasing preference of the US to bilateral negotiations reflects that the latter is easier for certain sensitive sectors to negotiate than the multilateral negotiations in the WTO with 150 members. The US uses regionalism, termed competitive liberalization, in order to impose its rules upon its trading partners, which are difficult to be accepted in the multilateral negotiations (Deblock $2005 \mathrm{a}$ ).
} 


\section{Bilateral trade agreements}

Bilateral trade agreements refer to all RTAs concluded between two countries that are not necessarily neighboring countries. As discussed earlier, these agreements can be concluded between countries with different development levels and for this reason, they are disparate in terms of scope and effectiveness. However, they still have some similar features.

First, most the bilateral agreements are FTAs, which do not envisage economic convergence. Establishing a FTA is less problematic than forming a CU or common market since the former does not require member countries to harmonize their external tariffs. This explains how North-South regionalism is possible within the framework of FTAs. Second, there has been an increasing tendency of establishing interregional RTAs. Supposing that establishing an integrated market is possible, to the extent that countries are close enough to one another, interregional RTAs would have a necessarily limited contribution in terms of trade effects. Motives for this type of RTAs are diverse, such as positioning as the center of international trade and investment (Wonnacott 1996), response to the pressure of globalization (Richard and Kirkpatrick 1999), and the domino effect (Baldwin 1995).

\section{Influences of the global financial crisis}

The 2008 2009 global financial crisis has been regarded as one of the most unprecedented events since the oil shocks of the 1970s, given its macroeconomic consequence on the real economy. It resulted in a deep recession in both advanced and emerging economies via financial and trade linkages. The global output fell by almost $2 \%$ in 2009, while the fall in trade was much more salient. In addition, global trade volume fell by $22 \%$ in 2009 . A number of studies assigned a large role for this decline in trade to the collapse in trade finance (Ahn et al. 2011, Chauffour and Malouche 2011) since the crisis had its origin in financial sectors that experienced bubbles in lax regulatory regimes during the pre-crisis period. From the trade side, protectionist measures taken by both advanced and emerging economies aggregated the fall in trade. Furthermore, a succession of measures was introduced around the globe to protect national industries, including the introduction of the Buy America clause in the US and a series of tariff increases in emerging economies. This situation raised concerns over trade conflicts 
experienced during the Great Depression in late 1920s.

\section{The global financial crisis and RTAs}

As far as RTAs are concerned, the immediate impact of the crisis was a delay in the conclusion of FTAs, which were under negotiation since the pre-crisis period. As governments worldwide focused on domestic policies against the background of the global crisis, the number of RTAs implemented during the crisis year was small compared to the pre-crisis level. Several FTAs were concluded during the crisis period. However, the negotiations for these FTAs had been concluded prior to October 2008, when the financial crisis struck with the bankruptcy of Lehman Brothers. ${ }^{21}$ However, the global financial crisis contributed to the reshuffling of the trade landscape and it provided momentum for trade agreements at the bilateral and regional levels, based on the following context.

First, many countries increasingly pay more attention to the efficiency of their trade policy, while some countries take protectionist measures for extended periods of time. In the context of outward-oriented economies, a crisis does force policymakers to place strong priority on boosting economic efficiency as a means of combating the crisis. During an economic downturn, there are greater opportunities to embrace even politically difficult reforms (Plummer 2009).

Second, a crisis often strengthens the cooperation with neighboring countries or trade partners since its spill-over effect and regional public goods are newly recognized. It has been frequently argued that the Asian financial crisis gave the initial push toward East Asian regionalism (Higgott 1998, Bustelo 2002, Lee 2012). Prior to the crisis, East Asian economic integration was exclusively formed by market forces, except for limited cases such as the AFTA. However, the crisis shed light on the cooperation at the regional level and it provided the momentum for more institutionalized integration based on bilateral and regional forums as well as agreements. The proliferation of bilateral FTAs since the late 1990s coincides with the recognition of region in East Asia.

Third, since the crisis, advanced economies, such as the EU and US, reinforced their trade policies based on actively seeking FTAs. EU's proactive FTA policy began with its

\footnotetext{
${ }^{21}$ In this regard, the FTAs of the US with Korea, Panama, and Peru are examples. The US Trade Representative signed FTAs with these three countries before the global financial crisis. However, their ratification process had been delayed in US Congress amidst the global financial crisis and the FTAS with Korea and Panama were implemented in 2011 and 2012, respectively. For example, the US-Peru FTA was implemented in early 2009, while it was signed in April 2006.
} 
2006 Global Europe Initiative, which was revitalized during the 2008 2009 crisis. The main reasons for this aggressive FTA policy were complex and multi-faceted. One of most important reasons was based on the fact that the contributions of external factors to economic recovery were extremely important, while domestic demand remained weak. In this context, creating far-reaching trade agreements with countries or regions with strong growth potentials was more appealing to both policy makers and business society. In the US, the crisis revoked the importance of industrial sectors for sustainable growth, while its economy had been increasingly reliant on financial sectors. The US government took the initiative of several industry support measures, including the national export initiative, and pushed for a more proactive FTA strategy. Its participation in the Pacific 4 (P4) talks (previous name of the TPP) in 2010 was a notable example.

\section{Main changes in RTAs}

What are the main changes in RTAs since the global financial crisis? It is empirically difficult to identify the direct influence of the crisis to current RTAs. However, some changes should be mentioned. First, current FTAs, particularly those involving large and advanced economies, such as the EU and the US, tend to be comprehensive ones. It is noteworthy that these FTAs increasingly cover regulatory issues. According to Horn et al. (2009), both the EU and the US include a wide range of WTO-plus and WTO-extra clauses. While the WTO-plus areas are often invoked in multilateral negotiation agendas with some success in limited cases, WTO-extra areas are new and highly related to domestic rule and practice (Table 6). There are some rationales why these areas should be included in trade agendas, but in some cases, the issues go beyond trade areas. In other cases, the term partnership agreement is used instead of free trade agreement. This trend is partially due to the self-recognition of advanced countries, such as e.g., the EU and the US, over their rule-making powers in trade-related areas. Hoekman and Winters (2007) term the rule-making under the FTAs involving the EU and the US as the hegemonic multilateralization of trade rules. In addition, they are able to impose their own model of FTAs on their partners, not necessarily coercively, but by the force of its market size. As different partners adopt the hegemon's approach over their own domestic ones, a degree of multilateralization is achieved (UNCTAD 2010). For the EU and the US, the main interest could be to use FTAs as a means of transferring the regulatory regimes of the EU 
and the US to other countries.

\section{Table 6. FTAs of EU, US, and WTO-extra provisions}

\begin{tabular}{|l|l|}
\hline \multicolumn{1}{|c|}{ Area covered } & \multicolumn{1}{c|}{ Content } \\
\hline Anti-corruption & $\begin{array}{l}\text { Regulations concerning criminal offence measures in matters affecting } \\
\text { international trade and investment. }\end{array}$ \\
\hline Competition policy & $\begin{array}{l}\text { Maintenance of measures to proscribe anticompetitive business conduct; } \\
\text { harmonization of competition laws; Establishment or maintenance of an } \\
\text { independent competition authority. }\end{array}$ \\
\hline Consumer protection & $\begin{array}{l}\text { Harmonization of consumer protection laws; exchange of information and } \\
\text { experts; training. }\end{array}$ \\
\hline Data protection & Exchange of information and experts; joint projects. \\
\hline Movement of capital & Liberalization of capital movement; prohibition of new restrictions. \\
\hline Labor market regulations & $\begin{array}{l}\text { Regulation of the national labor market; affirmation of International Labor } \\
\text { Organization (ILO) commitments; enforcement. }\end{array}$ \\
\hline $\begin{array}{l}\text { Intellectual Property } \\
\text { Rights (IPR) }\end{array}$ & Accession to international treaties not referenced in the TRIPs Agreement. \\
\hline $\begin{array}{l}\text { Approximation of } \\
\text { legislation }\end{array}$ & Application of EC legislation in national legislation. \\
\hline Audio visual & Promotion of the industry; encouragement of co-production. \\
\hline Civil protection & Implementation of harmonized rules. \\
\hline Innovation policies & Participation in framework programs; promotion of technology transfers. \\
\hline Cultural cooperation & Promotion of initiatives and local culture. \\
\hline Economic policy dialogue & Exchange of ideas and opinions; joint studies. \\
\hline Education and training & Measures to improve the general level of education. \\
\hline Energy & Exchange of information; technology transfer; joint studies. \\
\hline
\end{tabular}

\footnotetext{
${ }^{22}$ This regulation export approach is noticeable, particularly in the EU's trade policy based on active FTA policy. Its trade strategy paper for the years 2010 2015 clearly states that "enhanced regulatory cooperation... is an important aspect of our trade relationships particularly with our key partners, or as part of FTA or similar negotiations...” (European Commission 2010).
} 


\begin{tabular}{|l|l|}
\hline \multicolumn{1}{|c|}{ Area covered } & \multicolumn{1}{c|}{ Content } \\
\hline Financial assistance & Set of rules guiding the granting and administration of financial assistance. \\
\hline Health & $\begin{array}{l}\text { Monitoring of diseases; development of health information systems; } \\
\text { exchange of information. }\end{array}$ \\
\hline Illegal immigration & $\begin{array}{l}\text { Conclusion of re-admission agreements; prevention and control of illegal } \\
\text { immigration. }\end{array}$ \\
\hline Industrial cooperation & $\begin{array}{l}\text { Assistance in conducting modernization projects; facilitation and access to } \\
\text { credit to finance. }\end{array}$ \\
\hline Information society & Exchange of information; dissemination of new technologies; training. \\
\hline Research and technology & $\begin{array}{l}\text { Joint research projects; exchange of researchers; development of } \\
\text { public-private partnership. }\end{array}$ \\
\hline Taxation & Assistance in conducting fiscal system reforms. \\
\hline
\end{tabular}

(Source) Quoted from Horn et al. (2009).

Second, FTAs increasingly cover non-trade aspects such as labor and environment. Linking labor and environmental issues to trade dates back to the 1990s when several ministerial meetings at the WTO attempted to include these issues in the trade agenda. Early efforts were unsuccessful due to diverging perspectives between advanced economies, such as the US and the EU, and emerging economies. However, in bilateral FTAs, it is relatively easy to expand the negotiation agenda to non-trade issues, especially if contracting parties agree. The US has included labor issues to its FTAs since its NAFTA was established and this practice has been applied to subsequent FTAs that the US concluded with its trade partners. The EU has a similar approach in the sense that its FTAs cover labor issues together with environmental ones in the sustainable development chapter of its FTAs.

Third, plurilateral FTAs or mega-FTAs have been emerging among many bilateral FTAs. The TPP, RCEP, and to a lesser extent, the TTIP, are noticeable examples in this regard. These FTAs, mentioned as gravitational FTAs in the previous section, include some salient features. The trade and investment liberalization have allowed firms to have increasingly sophisticated and fragmented production lines on a regional and global scale. In this context, the multiplication of bilateral FTAs has caused the spaghetti bowl effect and overlapping rules of origin have become a burden for interweaving Global Value 
Chains (GVCs). Moreover, intertwined different rules of origin create complex global FTAs maps. Under these circumstances, it is necessary to prepare proper alternatives in order to minimize negative effects, such as trade diversion and transaction costs, and administrative outcomes. Consequently, multilateralizing bilateral FTAs is the subsequent step from the efficiency point of view, especially if a multilateral trading system does not deliver tangible outcomes on reducing trade barriers. Two questions arise in this regard. First, how much coverage will these mega-FTAs have? And second, will they be deep integration or shallow integration in nature?

Global trade order has been changing from the multilateralism based on the GATT/WTO to mega-FTAs, such as the TPP and the RCEP, especially during the period dominated by bilateral RTAs. The future of regionalism depends on how these emerging mega-FTAs develop. The first prospect is related to the relationship between the TPP and the RCEP. The TPP negotiation was recently finalized and it will enter into the ratification process, while the less ambitious RCEP is still under negotiation. As previously discussed, the relationship between two mega-FTAs is competitive and complementary at the same time. In some countries, such as Japan and some ASEAN members, there is double membership. If the TPP is successfully implemented with tangible effects, not only in tariffs but also in regulation related issues, then more countries would join the TPP. Meanwhile, the RCEP may lose its attractiveness as a regional free trade scheme. However, if the TPP faces unexpected obstacles during its ratification process, due to its comprehensive nature, then the RCEP may be regarded as a possible alternative to the TPP.

\section{Conclusion}

This paper examined the development and different typologies of economic regionalism. The findings of this analysis are as follows. First, while Balassa's typology classifies economic integration schemes according to advances, in reality, such schemes (RTAs) are FTAs, which are considerably disparate in several aspects. The EU has shown the most advanced form of integration and it remains a remarkable exception. Given that economic integration that goes beyond a FTA requires certain political negotiations as well as harmonization of economic policies, it is difficult to imagine that 
another EU-modeled regionalism will appear. Hence, FTAs become a broad category of RTAs in which preferential liberalizations differ in terms of coverage, geography, and the level of members' development. These findings have led researchers to revise and rebuild typologies of regionalism according to the scope of liberalization (shallow/deep integration), the relationship between a certain legal form and its actual effectiveness (de jure/de facto integration), and the level of openness (closed/open regionalism).

Second, RTAs should be understood in their interactions with external factors such as multilateralism, globalization, and other RTAs. This is important for two reasons. On the one hand, including the external factors makes it possible to differentiate between seemingly similar types of RTAs according to timing. Recent RTAs can be regarded as responses to a new trade environment: multilateral negotiations agenda and globalization. This is probably why recent RTAs are often termed as WTO-plus. On the other hand, this external factor-based approach allows for the identification of relevant arguments of recent new regionalism.

Third, this paper focused special attention on the number of participants in a RTA, which allowed us to classify RTAs into three types: plurilateral, gravitational, and bilateral. Most RTAs, especially East Asian ones, are bilateral ones. It is noteworthy that some relatively small and open countries are very active in establishing RTAs with their larger trading partners. Recent developments of mega-FTAs, such as the TPP and the RCEP, have been changing the landscape of RTAs since they involve a large number of countries, which had been very active in bilateral FTAs. The emergence of these megaFTAs can be a subsequent step toward the multiplication of bilateral FTAs, which has created the spaghetti bowl effect in the rules of origin. Meanwhile, they also seem to be influenced by the consequences of the 2008 2009 global financial crisis. Table 7 summarizes all of the typologies of regional economic integration and their criteria. 
Table 7. Typology and criteria of regional economic integration

\begin{tabular}{|c|c|c|c|c|c|c|c|}
\hline Typology & Criteria & \multicolumn{6}{|c|}{ Groups of regional economic integration } \\
\hline Balassa & $\begin{array}{l}\text { Advance of } \\
\text { Integration }\end{array}$ & FTA & $\begin{array}{l}\text { Customs } \\
\text { Union }\end{array}$ & $\begin{array}{l}\text { Common } \\
\text { Market }\end{array}$ & $\begin{array}{r}\text { Eco } \\
\mathrm{U}\end{array}$ & $\operatorname{mic}$ & $\begin{array}{c}\text { Monetary } \\
\text { Union }\end{array}$ \\
\hline $\begin{array}{l}\text { Feature of Economic } \\
\text { integration }\end{array}$ & $\begin{array}{l}\text { Level of } \\
\text { Institutionalization }\end{array}$ & \multicolumn{3}{|c|}{ De jure integration } & \multicolumn{3}{|c|}{ de facto integration } \\
\hline Membership & $\begin{array}{l}\text { Is the membership } \\
\text { open to other countries? }\end{array}$ & \multicolumn{3}{|c|}{ Closed integration } & \multicolumn{3}{|c|}{ Open regionalism } \\
\hline $\begin{array}{l}\text { Coverage of } \\
\text { Liberalization }\end{array}$ & $\begin{array}{l}\text { How far does a trade } \\
\text { agreement cover } \\
\text { beyond tariff issues? }\end{array}$ & \multicolumn{3}{|c|}{ Shallow integration } & \multicolumn{3}{|c|}{ Deep integration } \\
\hline $\begin{array}{l}\text { Relation Between } \\
\text { Market and authority }\end{array}$ & & \multicolumn{2}{|c|}{$\begin{array}{l}\text { Regulation and } \\
\text { sanction }\end{array}$} & \multicolumn{2}{|c|}{$\begin{array}{c}\text { Risk } \\
\text { management }\end{array}$} & \multicolumn{2}{|c|}{$\begin{array}{l}\text { Regulated } \\
\text { market }\end{array}$} \\
\hline $\begin{array}{l}\text { Number of } \\
\text { participants }\end{array}$ & $\begin{array}{l}\text { How many countries } \\
\text { are involved in a RTA? }\end{array}$ & \multicolumn{2}{|c|}{ Plurilateral } & \multicolumn{2}{|c|}{ Gravitational } & \multicolumn{2}{|c|}{ Bilateral } \\
\hline
\end{tabular}

Finally, this paper includes limitations in that it does not provide a clear-cut method regarding how to classify different RTAs or how to establish WTO-friendly RTAs. These limits are largely due to the fact that the number of countries seeking RTAs has been unprecedented and their motives are complex. However, this exploratory study opens the door for further research on RTAs in that mega-RTAs can change the landscape of overlapping bilateral RTAs. It is particularly important to harmonize different RTAs and provide a template of standard RTAs in order to prevent the spaghetti bowl effect from occurring.

Received 3 October 2015, Revised 6 January 2016, Accepted 26 April 2016

\section{References}

Ahn, JaeBin, Mary Amiti,and David E. Weinstein. "Trade Finance and the Great Trade Collapse.” American Economic Review, 101, no.3 (2011): 298-302. 
Balassa, Bela. The Theory of Economic Integration. Homewood: Richard Irwin, 1961.

Baldwin, Richard E. Towards an integrated Europe. London: Centre for Economic Policy Research, 1994.

Baldwin, Richard E. "A Domino Theory of Regionalism." in Expanding Membership of the European Union, edited by Richard E., Haaparnata and Jaakko Kiander. Cambridge: Cambridge University Press, 1995.

Bergsten, Fred C. "APEC and World Trade: A Force for Worldwide Liberalization." Foreign Affairs, 73, no.3 (1994): 22-26.

Bergsten, Fred C. Open Regionalism. Washington. D.C.: Institute for International Economics, 1997.

Bhagwati, Jagdish. "U.S. Trade Policy: The Infatuation with Free Trade Areas." The Dangerous Drift to Preferential Trade Agreements, edited by Jagdish Bhagwati and Anne O. Krueger. Washington, D.C.: American Enterprise Institute for Public Policy Research, 1995.

Breslin, Shaun and Richard Higgott. "Studying Regions: Learning from the Old, Constructing the New." New Political Economy, 5, no.3 (2000): 333-352.

Blomstrom, Magnus and Ari Kokko. "Regional Integration and Foreign Direct Investment." CEPR Discussion Papers 1659, London: Centre for Economic Policy Research, 1997.

Bustelo, Pablo, "Regionalism in East Asia: Paradigm Shifting?" The Impact of the Financial Crises on East Asian Regionalism, edited by Liu, Fu-kuo and Pilippe Rénier. London: Routledge-Curzon, London, 2002.

Castells, Manuel. La société en réseaux. Paris: Fayard, 1998.

Chauffour, Jean-Pierre and Mariem Malouche. Trade Finance during the Great Trade Collapse. Washington DC: The World Bank, 2011.

Council of Economic Advisors. Economic Report of the President. Washington D.C.: Council of Economic Advisors, 1995.

Deblock Christian. "Les États-Unis et la libéralisation de l'investissement." Globalisation et pouvoir des entreprises, edited by Michèle Rioux. Montréal: Athéna Éditions, 2005(a). 
Deblock, Christian. "Régionalisation économique et mondialisation: Que nous apprennent les théories?" Centre Études internationales et Mondialisation. Cahier de recherche no.05-07, 2005(b).

Deblock, Christian, Dorval Brunelle and Michèle Rioux. "Chapter 22 Intégration euroméditeranéenne et stratégies économiques." Zone de libre-échange des Amériques et intégration en profondeur asymétrique, edited by Henri Regnault. Paris: Harmattan, 2004.

Delmas-Marty, Mireille. Trois défis pour un droit mondial. Paris: Seuil, 1998.

D’Arcy, François. Les politiques de l'Union européenne. Paris: Montchrestien, 2003.

European Commission. Trade, Growth and World Affair: Trade Policy as a Core Component of the EU's 2020 Strategy. COM (2010)612, 2010.

Ethier, Wilfred J. “The New Regionalism.” The Economic Journal, 108, no.449 (1998): 1149-1161.

Fernandez, Raquel. "Returns to Regionalism: An Evaluation of Non-traditional Gains from RTAs." CEPR Discussion Papers 1634, London: Centre for Economic Policy Research. 1997.

Figuière, Catherine and Laëtitia Guilhot. "Caractériser les processus régionaux: les apports d'une approche en termes de coordination." Mondes en Développement, 135(2006): 79-100.

Fishlow, Albert and Stephan Haggard. The United States and the Regionalization of the World Economy. Paris: OECD Development Center Research Project on Globalization and Regionalization, 1992.

Gaulier, Guillaume, Sébastien Jean and Deniz Ünal-Kensenci. "Regionalism and the Regionalisation of International Trade. " Document de travail du CEPII, no.2004-16, Paris: Centre français d'étude et de recherche en économie internationale (CEPII), 2004.

Haggard, Stephan. "Regionalism in Asia and the Americas." The Political Economy of Regionalism, edited by Edward. D. Mansfield and Helen Milner. New York: Columbia University Press, 1997.

Higgott, Richard, "The Asian Economic Crisis: a Study in the Politics of Resentment." New Political Economy, 3, no.3: 333-356. 
Horn, Henrik, Petros C. "Mavroidis and André Sapir, Beyond the WTO? An Anatomy of the EU and US Preferential Trade Agreements." Bruegel Blueprint Series 7, Brussles: Bruegel, 2009.

Hugon, Philippe. Les économies en développement à l'heure de la régionalisation. Paris: Karthala, 2003.

Kaiser, Karl. "The Interaction Regional Subsystems: Some Preliminary Notes on Recurrent Patterns and the Role of Superpowers." World Politics, 21, no.1 (1968): 84107.

Kébabdjian, Gérard. Europe et globalisation. Paris: L'Harmattan, 2006.

Krueger, Anne O. "Free Trade Agreements as Protectionist devices: Rules of Origin." NBER Working Paper 4352, National Bureau of Economic Research, 1993.

Lal, Deepak. "Trade Blocs and Multilateral Free Trade." Journal of Common Market Studies, 31, no.3 (1993): 349-358.

Lawrence, Robert Z. Regionalism, Multilateralism and Deeper Integration. Washington D.C: Brookings Institution, 1996.

Lee, Seungjoo, "The Evolutionary Dynamics of Institutional Balancing in East Asia". East Asia Institute Working Paper, February, 2012.

Mansfield, Edward D. and Helen V. Milner. "The New Wave of Regionalism." International Organization, 53, no.3 (1999): 589-627.

Oman, Charles. "Globalisation et régionalisation : quels enjeux pour les pays en développement?" Paris: Etudes du Centre de Développement OCDE, 1994.

Panagariya, Arvind. "The Regionalism Debate: An Overview." The World Economy, 44, no.4 (1999): 477-511.

Petit, Pascal. "Mondialisation et régionalisation: une analyse comparative de la construction es rapports internationaux en Europe et en Asie de l'Est." CEPREMAP Document de travail no. 2003-13, 2003.

Regnault, Henri. "Une lecture comparative des accords d'association euro-méditerranéens et de l'Accord Nord-Américain de Libre-échange (ALENA)" in Intégration euroméditerranéenne et stratégie économiques, edited by Henri Regnault. Paris: L’Harmattan, 2003. 
Regnault, Henri. "Libre-échange Nord-Sud et typologie des formes d'internationalisation des économies." Région et Développement 22 (2005): 19-38.

Ruggie, John G. "Multilateralism: Anatomy of an Institution.” International Organization 46 (1992): 561-598.

Santa Cruz, Herman. "The Creation of the United Nations and ECLAC." CEPAL Review 57 (1996): 17-33.

Sapir, André. "The Political Economy of EC Regionalism.” European Economic Review, 42, no.3-5 (1998): 717-732.

Schott, Jeffrey J. "More Free Trade Areas?" in Free Trade Areas and U.S. Trade Policy, edited by Jeffrey Schott. Washington D.C.: Institute for International Economics, 1989.

Summers, Laurence H. "Regionalism and the World Trading System.” (paper presented at the symposium "Policy Implications of Trade and Currency Zones" organized by Federal Reserve Bank of Kansas City, Jackson Hole, August 22-24, 1991).

UNCTAD, International Trade after the Economic Crisis: Challenges and New Opportunities. United Nations, 2010.

Webber, Douglas. "Two Funerals and a Wedding? The Ups and Downs of Regionalism in East Asia and Asia-Pacific after the Asian Crisis." Pacific Review, 14, no.3 (2001): 339-372.

Winters, Alan L. "The European Community: a Case of Successful Integration." in New dimensions in regional integration, edited by Jaime De Melo and Arvind Panagariya. Cambridge: Cambridge University Press, 1993.

Wonnacott, Ronald J. "Free-Trade Agreements: For Better or Worse?" American Economic Review, 86, no. 2 (1996): 62-66.

World Trade Organization. https://www.wto.org/english/tratop_e/region_e/regfac_ e.htm (Accessed July 5, 2015); http://rtais.wto.org/UI/PublicAllRTAList.aspx (Accessed July 15, 2015); https://www.wto.org/english/tratop_e/region_e/region_e.htm (accessed August 10, 2015). 


\section{Appendix}

\section{Acronyms of regional trade agreements and organizations}

- ACS: Association of Caribbean States /Association des Etats de la Cara'ibe

- AG: Andean Group

- APEC: Asia-Pacific Economic Cooperation

- ACM: Arab Common Market

- ASEAN: Association of Southeast Asian Nations/Association des nations de l'Asie du Sud-Est

- CACM: Central American Common Market/Marche Commun Centramericain (MCCA)

- CARICOM: Caribbean Community

- CEFTA: Central European Free Trade Agreement/Accord de libre-echange centreeuropeen (ALECE)

- CEMAC: Communaute economique et monetaire de l'Afrique centrale/Economic and Monetary Community of Central Africa

- CEPGL: Communaute economique des Pays des Grands Lacs

- CIS: Commonwealth of Independent States/Communaute des Etats independants (CEI)

- COMESA: Common Market for Eastern and Southern Africa/Marche commun de l'Afrique orientale et australe

- Cross Border Initiative: Cross-Border Initiative in Eastern and Southern Africa

- EAC: East African Community/Communaute d'Afrique de l'Est

- EAEG: East Asian Economic Group

- ECCAS: Economic Community of Central African States/Communaute Economique des Etats d'Afrique Centrale

- ECO: Economic Cooperation Organization

- ECOWAS: Economic Community of West African States/Communaute economique des

Etats de l'Afrique de l'Ouest (CEDEAO)

- EFTA: European Free Trade Association/Association europeenne de libre-echange (AELE)

- EMFTA: Euro-Mediterranean Free Trade Area/Zone de libre echange Euro-Mediterraneenne

- EU: European Union/Union europeenne (UE) 
- FTAA: Free Trade Area of the Americas/Zone de libre-echange des Ameriques (ZLEA)

- GAFTA: Greater Arab Free Trade Area/Grande zone arabe de libre-echange

- GCC: Gulf Cooperation Council /Conseil de cooperation du Golfe (CCG)

- LAIA: Latin American Integration Association

- NAFTA: North American Free Trade Agreement/Accord de libre-echange nordamericain (ALENA)

- MERCOSUR: Mercado Comun del Sur (in Spanish), Mercado Comum do Sul (in Portuguese)

- MRU: Mano River Union/Union du fleuve Mano

- SAARC: South Asian Association for Regional Cooperation/Association sud-asiatique pour la cooperation regionale

- SADC: Southern African Development Community/Communaute de developpement d'Afrique australe

- ICO: Indian Ocean Commission/Commission de l'ocean Indien (COI)

- UDEAC: Union des Etats d'Afrique Centrale/Customs and Economic Union of Central Africa

- UEMOA: Union economique et monetaire ouest-africaine/West African Economic and Monetary Union

- UMA: Union du Maghreb Arabe/Arab Maghreb Union 